\title{
Pembinaan Kesenian Gunungan di Gondang Sari, Ketep Magelang, Jawa Tengah
}

\author{
Indah Nuraini \\ Jurusan Tari, Fakultas Seni Pertunjukan \\ Institut Seni Indonesia Yogyakarta \\ Jalan Parangtritis Km 6,5, Sewon, Bantul, Daerah Istimewa Yogyakarta 55188 \\ No. Tlp.: +6287850043027, E-mail: nurainiindah661@gmail.com
}




\title{
Pembinaan Kesenian Gunungan di Gondang Sari, Ketep Magelang, Jawa Tengah
}

\author{
Indah Nuraini \\ Jurusan Tari, Fakultas Seni Pertunjukan \\ Institut Seni Indonesia Yogyakarta \\ Jalan Parangtritis Km 6,5, Sewon, Bantul, Daerah Istimewa Yogyakarta 55188 \\ No. Tlp.: +6287850043027, E-mail: nurainiindah661@gmail.com
}

\begin{abstract}
Abstrak
Tari Gunungan merupakan sebentuk kesenian baru dalam Kelompok Kesenian Gunungan Dusun Gondang Sari yang dibuat pada tahun 2016 dengan bantuan mahasiswa ISI Yogyakarta pada program P3Wilsen dari LPM ISI Yogyakarta. Selanjutnya oleh masyarakat dusun ini, Gunungan dijadikan sebagai salah satu kesenian andalan dan identitas kesenian setempat. Penyuluhan ini bertujuan melakukan pembinaan seni kepada Kelompok Kesenian Gunungan yang berada di Gondang Sari, Ketep, Sawangan, Magelang, Jawa Tengah. Program dari LPM ISI Yogyakarta ini dilaksanakan selama lima bulan dari Maret hingga Agustus 2020, terjeda oleh masa krisis pandemi Covid-19. Metode yang diterapkan adalah ceramah, workshop, dan evaluasi. Materi penyuluhan ini adalah menyangkut teori dan praktik kesenian Gunungan. Hasil penyuluhan yang didapatkan meliputi tiga hal, yakni pembenahan gerak tari, pembenahan pola lantai dan koreografi, serta pembuatan kemasan tari Gunungan sebagai sajian pariwisata.
\end{abstract}

Kata kunci: penyuluhan seni, tari Gunungan, Gondang Sari

\section{Gunungan Art Guidance in Gondang Sari, Ketep, Magelang, Central Java}

Abstract

Gunungan dance is a form of contemporary art in Gunungan Art Group in Gondang Sari village, first established in 2016 with the help from students from Indonesian Institute of Arts Yogyakarta (ISI Yogyakarta) in contribution to P3Wilsen program from LPM ISI Yogyakarta. The group thrives on from the help of locals and Gunungan becomes one of trademark and art identity in the area. The training aims to deliver art guidance to Gunungan Art Group in Gondang Sari, Ketep, Sawangan, Magelang, Central Java. This LPM ISI Yogyakarta program is done in five months from March to August 2020, slightly delayed due to Covid-19 pandemic crisis. The method applied are lecture, workshop, and evaluation. The training lesson material covers Gunungan art theory and practices. There are three results gained, which are the improvement of dance moves, improvement in floor patterning and choreography, and the built of Gunungan dance as a form of dance attraction for tourism.

Keywords: art guidance, Gunungan dance, Gondang Sari 


\section{PENDAHULUAN}

Dusun Gondang Sari, Desa Ketep adalah salah satu daerah wilayah Kabupaten Magelang Jawa Tengah, yang berdekatan dengan Gunung Merapi dan Gunung Merbabu. Wilayah ini merupakan lokasi yang sangat eksotis. Penggemar landscape bisa mengabadikan sunrise dengan latar belakang Gunung Merapi yang megah, areal pertanian masyarakat yang membentuk kontur indah hingga gugusan perbukitan dan gunung yang berdiri berjajar serupa benteng penjaga. Di wilayah ini terdapat lokasi wisata terkenal bernama Ketep Pass. Disebutkan oleh Prastiwi \& Farida (2016:69), Ketep Pass adalah objek wisata alam di puncak bukit sawangan yang terletak di pertengahan antara gunung Merapi dan Gunung Merbabu. Secara administratif, tempat wisata alam yang mengkhususkan pada kegunungapian ini berada di Kabupaten Magelang, Jawa Tengah. Bukit Ketep Pass memiliki ketinggian sekitar 1.200 meter dpl dan luas area sekitar 8.000 meter persegi. Selain itu, terdapat banyak kegiatan kesenian dan kebudayaan di sekitar Gunung Merapi ini, yang menyatu dalam kehidupan masyarakat. Ini sangat menarik untuk dipelajari karena di wilayah ini antara ritus desa dan kesenian, kegiatan muda-mudi, dan kesuburan alam masih tetap dijaga oleh masyarakatnya.

Gondang Sari, Ketep, Sawangan, Magelang, Jawa Tengah mempunyai kesenian yang disebut dengan kesenian Gunungan. Kesenian ini termasuk kesenian yang baru, karena baru dibuat atas saran Arifin sebagai lurah Desa Ketep kepada kelompok kesenian dusun Gondang Sari dan dibantu oleh mahasiswa ISI yogyakarta yang pada saat itu mengikuti kegiatan program P3Wilsen yang diadakan oleh LPM ISI Yogyakarta pada tahun 2016. Akan tetapi berhubung waktunya sangat terbatas, pembentukan kesenian Gunungan tersebut dirasa belum selesai dan belum sempurna. Menurut para anggota, kesenian tersebut mempunyai bentuk dan ciri khas yang berbeda dibandingkan dengan kesenian yang lain sehingga menarik. Mereka pun masih sangat ingin mempelajari kesenian tersebut yang diharapkan akan menjadi kesenian khas Dusun Gondang Sari. Yang menjadi permasalahan utama adalah tidak ada pelatih yang berkompeten di bidang ini sehingga kesenian ini belum bisa terealisasikan. Pada saat Institut Seni Indonesia Yogyakarta mengadakan Program P3Wilsen lagi pada tahun 2018 di wilayah tersebut, kesenian Gunungan ini pun belum sempat mendapatkan pembinaan, mengingat program tersebut sangat terbatas baik dalam hal waktu maupun kegiatannya. Ini disebabkan oleh pelaksanaan pembinaan kesenian yang dilakukan tidak terpusat pada satu kelompok saja melainkan pada beberapa kelompok di wilayah tersebut. Oleh karena itu, kesenian Gunungan ini perlu mendapatkan pembinaan kembali. Sesuai dengan keinginan kelompok Kesenian Gunungan ini, pada program penyuluhan yang diadakan oleh LPM ISI Yogyakarta tahun 2020 kesenian Gunungan bisa mendapatkan lagi kesempatan untuk dibina secara intensif. Solusi yang ditawarkan terpusat pada tiga hal, yakni pembenahan gerak tari, pembenahan pola lantai dan koreografi, serta pembuatan kemasan tari Gunungan sebagai sajian pariwisata. 


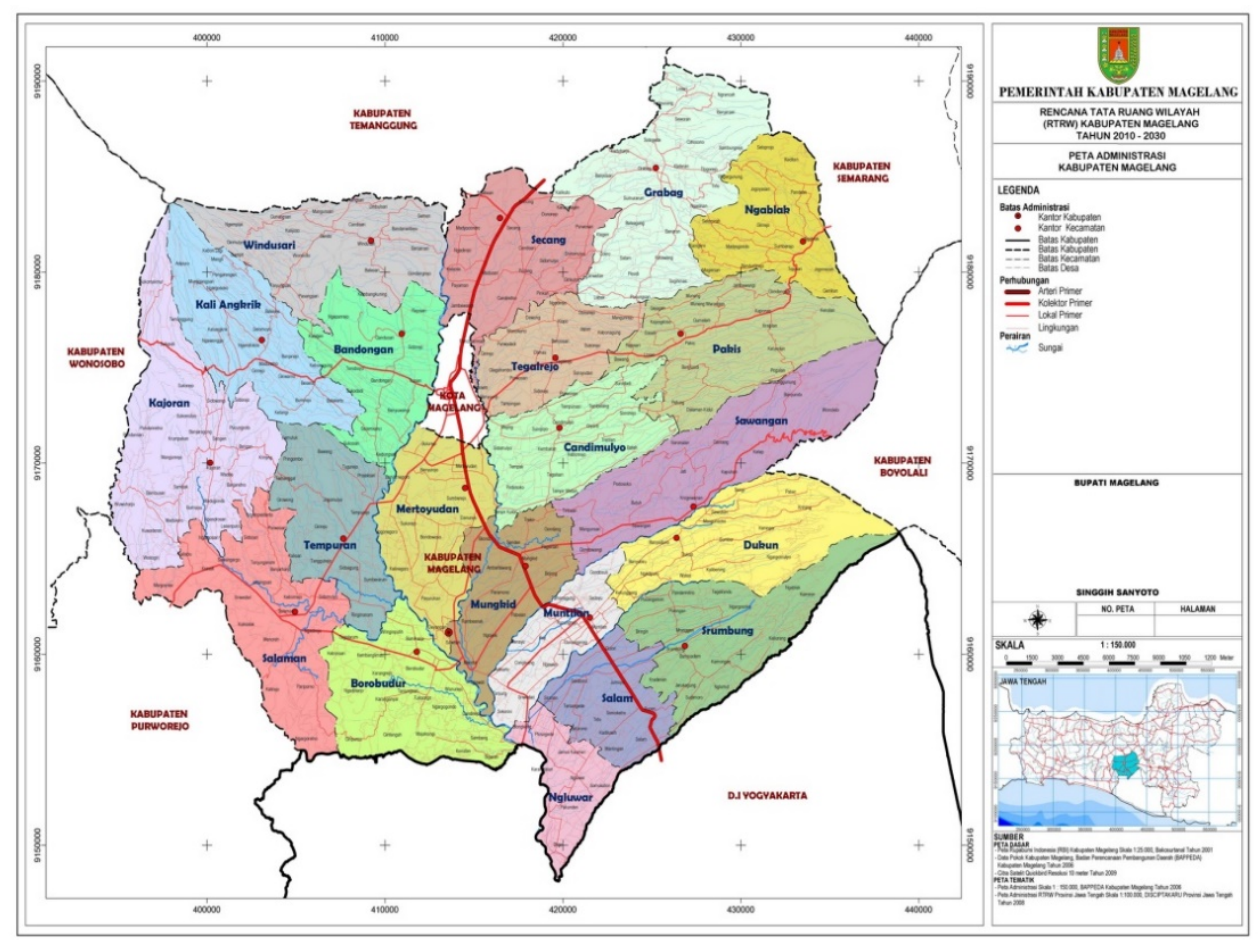

Gambar 1 Denah lokasi kegiatan

Tujuan program penyuluhan ini adalah mewujudkan salah satu unsur Tri Dharma Perguruan Tinggi, yaitu pengabdian kepada masyarakat, khususnya dalam bidang seni pertunjukan bagi kelompok kesenian Gunungan, di Gondang Sari, Ketep, Sawangan, Magelang, Jawa Tengah. Tujuan lain adalah menerapkan ilmu pengetahuan dan seni yang telah dipelajari sesuai dengan teori sehingga dapat memberikan manfaat langsung kepada masyarakat.

Adapun manfaat program ini bagi masyarakat adalah mendapatkan pengalaman dan pengetahuan dari perguruan tinggi seni Institut Seni Indonesia Yogyakata. Bagi dosen, program ini dapat memperluas jejaring dengan seniman tradisi dan menambah pengetahuan tentang kesenian rakyat yang berkembang di daerah Ketep, Sawangan, Magelang. Pemerintah daerah pun mendapatkan manfaat karena pelestarian dan pengembangan budaya di daerahnya ikut terbantu, terutama di dalam bidang seni tari. Selain itu, potensi seni di daerahnya pun ikut bertambah. Bagi perguruan tinggi, program ini membantu mendapatkan informasi serta masukan dan data tentang kegiatan seni yang berkaitan dengan seni pertunjukan tari karena secara tidak langsung pembinaan ini adalah salah satu kegiatan untuk mempromosikan perguruan tinggi yang terkait.

\section{METODE PENGABDIAN}

Materi penyuluhan menyangkut teori dan praktik kesenian Gunungan. Metode yang diterapkan adalah ceramah, workshop, dan evaluasi. Melalui ceramah, penyuluh memberikan penjelasan secara lisan dan memberikan contoh gerakan-gerakan tari secara imitasi. Semua peserta melakukan gerak tari baik secara bagian per bagian maupun secara keseluruhan dengan workshop. Evaluasi dilakukan penyuluh mengoreksi dan 
melakukan pembenahan pada gerakan tari, koreografi, dan pola lantai yang belum baik.

\section{HASIL DAN PEMBAHASAN}

Tari Gunungan menggunakan properti gunungan seperti yang lazim ditemui dalam wayang kulit purwa. Menurut Sunyoto dan Angge 2016:319), "Pengertian gunungan wayang kulit purwa adalah tokoh/boneka wayang kulit purwa berupa tiruan gunung yang runcing seperti tumpeng. Gunungan juga disebut kayon karena salah satu unsur pokok wayang ini adalah kayu (wit) atau pohon".
Khalayak sasaran penyuluhan ini adalah kelompok kesenian Gunungan. Kegiatan ini bertempat di Gondang Sari, Ketep, Sawangan, Magelang, Jawa Tengah. Waktu pelaksanaan dimulai dari 10 Maret sampai dengan 30 Agustus 2020, sebanyak 12 kali pertemuan. Total waktu pelaksanaan adalah lima bulan. Jadwal penyuluhan tidak kaku, tetapi menyesuaikan dengan situasi dan kondisi penyuluh dan masyarakat setempat. Begitu pula dengan durasi setiap pertemuan yang disesuaikan dengan situasi, kondisi, dan kebutuhan sehingga bervariasi antara 2, 3, dan 4 jam per pertemuan.

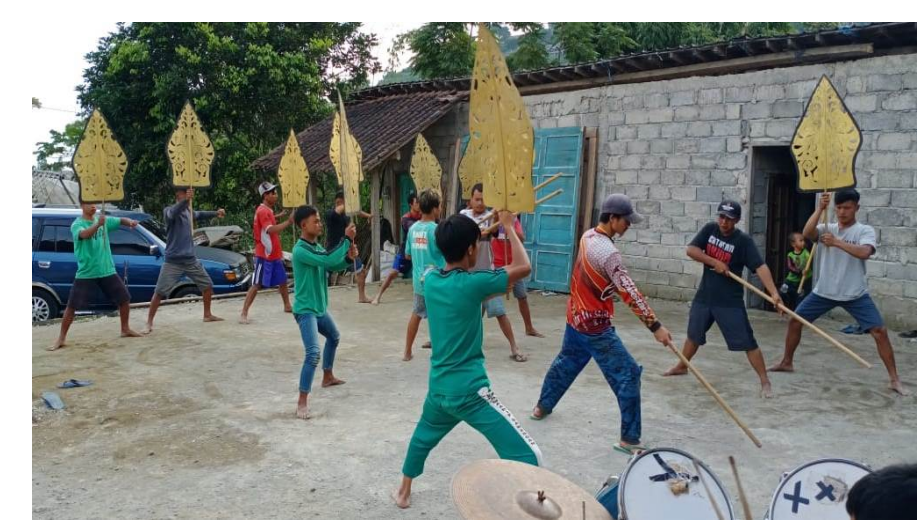

Gambar 2 Latihan cara menggerakkan properti gunungan dan tongkat

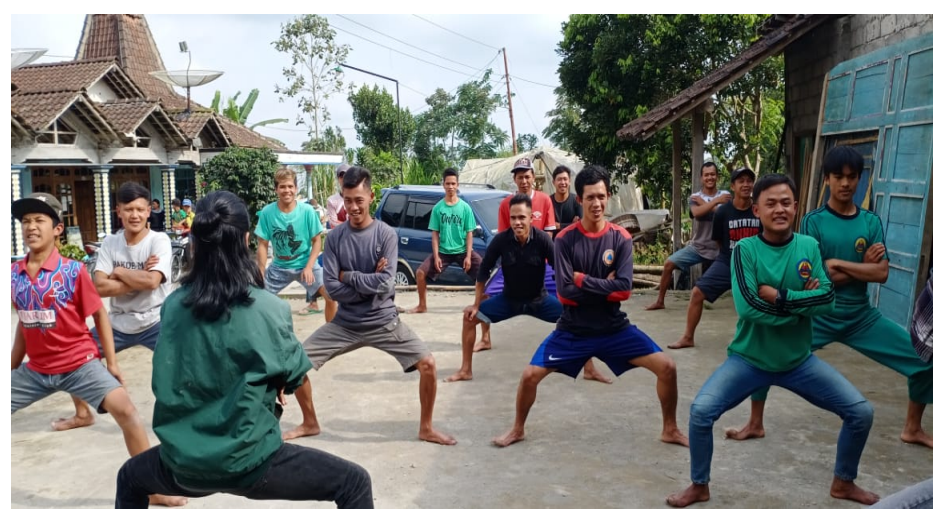

Gambar 3 Latihan untuk sikap mendhak dalam menari 


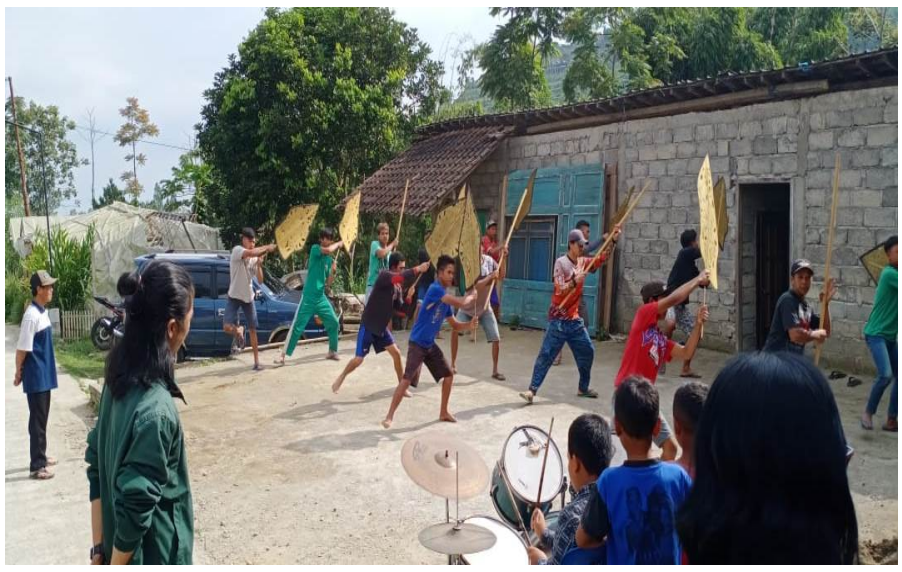

Gambar 4 Latihan untuk menyeragamkan gerak

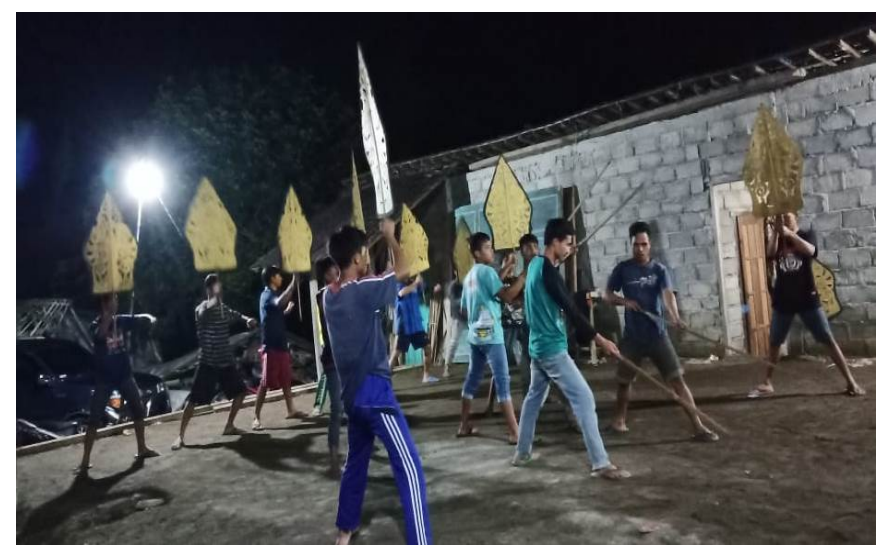

Gambar 5 Latihan dengan pola lantai

Tabel 1 Jadwal Kegiatan Penyuluhan

\begin{tabular}{cll}
\hline No. & \multicolumn{1}{c}{ Hari/Tanggal/Jam } & \multicolumn{1}{c}{ Rincian Kegiatan } \\
\hline 1 & Kamis, 12 Juni 2020 & - Penerjunan/penyerahan dosen penyuluh di Kelurahan Ketep, \\
& Pukul 11.00-13.00 & Sawangan, Magelang, Jawa Tegah. \\
& & - Mengadakan koordinasi dengan ketua kelompok kesenian \\
& & Gunungan. \\
\hline 2 & Sabtu, 14 Juni 2020 & Memberikan pengarahan untuk gerak-gerak kaki dan tangan \\
& Pukul 20.00-23.00 & yang belum dilakukan secara kompak/bersama-sama serta \\
& & memberikan pengarahan untuk susunan koreografi tarinya yang \\
& & belum menarik. \\
\hline 3 & Jumat, 20 Juni 2020 & Membetulkan teknik-teknik sikap dan bentuk tubuh serta gerak \\
& Pukul 20.00-23.00 & kaki dan gerak tangan. \\
\hline 4 & Sabtu, 13 Juni 2020 & Membetulkan teknik-teknik sikap dan bentuk tubuh serta gerak \\
& Pukul 16.00 - 21.00 & kaki dan gerakn tangan. \\
\hline 5 & Selasa, 16 Juni 2020 & Membuat susunan koreografi tarinya. \\
& Pukul 14.00 - 20.00 & \\
\hline
\end{tabular}




\begin{tabular}{|c|c|c|}
\hline 6 & $\begin{array}{l}\text { Kamis, } 18 \text { Juni } 2020 \\
\text { Pukul } 20.00-23.00\end{array}$ & Membuat susunan koreografi tarinya. \\
\hline 7 & $\begin{array}{l}\text { Senin, } 22 \text { Juni } 2020 \\
\text { Pukul } 20.00-23.00\end{array}$ & Membuat pola lantai. \\
\hline 8 & $\begin{array}{l}\text { Jumat, } 26 \text { Juni } 2020 \\
\text { Pukul } 20.00-23.00\end{array}$ & Membuat pola lantai. \\
\hline 9 & $\begin{array}{l}\text { Senin, } 29 \text { Juni } 2020 \\
\text { Pukul } 20.00-23.00\end{array}$ & $\begin{array}{l}\text { Latihan kesenian Gunungan dengan sudah menerapkan sikap } \\
\text { tubuh, juga gerak kaki dan tangan yang sesuai dengan susunan } \\
\text { koreografi dan pola lantai yang telah ditentukan. }\end{array}$ \\
\hline 10 & $\begin{array}{l}\text { Senin, 20 Juli } 2020 \\
\text { Pukul } 20.00-24.00\end{array}$ & $\begin{array}{l}\text { Masih melakukan pembenahan-pembenahan dalam hal } \\
\text { kekompakan atau keseragaman gerak. }\end{array}$ \\
\hline 11 & $\begin{array}{l}\text { Jumat, 24 Juli } 2020 \\
\text { Pukul } 14.00-17.00\end{array}$ & $\begin{array}{l}\text { Latihan sudah sesuai dengan ketentuan yang sudah disepakati } \\
\text { bersama. }\end{array}$ \\
\hline 12 & $\begin{array}{l}\text { Jumat, } 7 \text { Agustus } 2020 \\
\text { Pukul } 20.00-23.00\end{array}$ & Latihan hasil penyuluhan yang sudah tertata. \\
\hline 13 & $\begin{array}{l}\text { Jumat, } 14 \text { Agustus } 2020 \\
\text { Pukul } 15.00-17.00\end{array}$ & $\begin{array}{l}\text { Penyajian hasil penyuluhan kesenian Gunungan yang dihadiri } \\
\text { dari LPM ISI Yogyakarta yang diwakili oleh Edy Subagyo dan } \\
\text { Haris Natanael. }\end{array}$ \\
\hline
\end{tabular}

Tabel 2 Daftar Peserta Penyuluhan

\begin{tabular}{clll}
\hline No. & \multicolumn{1}{c}{ Nama Peserta } & \multicolumn{1}{c}{ Keanggotaan } & \multicolumn{1}{c}{ Alamat } \\
\hline 1 & Sutrisno & Ketua & Gondang Sari \\
\hline 2 & Ridwan Maulana & Penari & Gondang Sari \\
\hline 3 & Shodikin & Penari & Gondang Sari \\
\hline 4 & Priana & Penari & Gondang Sari \\
\hline 5 & Nur Widodo & Penari & Gondang Sari \\
\hline 6 & Ahmad Syumandon & Penari & Gondang Sari \\
\hline 7 & Tri Istanto & Penari & Gondang Sari \\
\hline 8 & Sumardi & Penari & Gondang Sari \\
\hline 9 & Agus Yulianto & Penari & Gondang Sari \\
\hline 10 & Rizki & Penari & Gondang Sari \\
\hline 11 & Wiyono & Penari & Gondang Sari \\
\hline 12 & Komad & Penari & Gondang Sari \\
\hline 13 & Madi & Penari & Gondang Sari \\
\hline 14 & Suryanto & Penari & Gondang Sari \\
\hline 15 & Marsono Tumar & Pemusik & Gondang Sari \\
\hline 16 & Suryadi & Pemusik & Gondang Sari \\
\hline 17 & Dhoni Sutrisno & Pemusik & Gondang Sari \\
\hline 18 & Sutras & Pemusik & Gondang Sari \\
\hline 19 & Riyadi & Pemusik & Gondang Sari \\
\hline 20 & Tumar & Penari & \\
\hline & & & Gondang Sari \\
\hline
\end{tabular}


Terdapat beberapa kendala dalam pelaksanaan penyuluhan ini. Pada bulan Maret setelah penerjunan di lokasi, kegiatan berjalan lancar sesuai dengan jadwal yang telah disepakati dengan anggota binaan. Akan tetapi, menjelang akhir bulan Maret terjadi wabah Covid-19, yang memaksa pemerintah menghentikan semua kegiatan yang berhubungan dengan orang banyak termasuk kegiatan penyuluhan. Hal ini dilakukan supaya tidak terjadi penyebaran virus yang lebih banyak. Secara otomatis, dari April hingga Mei kegiatan berhenti total. Di samping itu, suasana di Dusun Gondang, Desa Ketep dari April hingga Mei tersebut sangat sepi dan banyak terjadi pembegalan. Oleh karena itu, penduduk tidak memperbolehkan penyuluh datang ke sana. Baru pada Juni daerah tersebut dinyatakan aman. Pemerintah pun sudah mulai memperbolehkan pelaksanaan kegiatan di daerah yang aman dari Covid-19 termasuk di Dusun Gondang Sari. Dengan demikian, kegiatan penyuluhan bisa mulai berjalan kembali.

Setelah dilakukan pembinaan dari penyuluhan seni dari ISI Yogyakarta, didapatkan hasil yang menggembirakan. Pertama, para peserta mendapatkan apresiasi dan wawasan yang lebih luas tentang seni tari di dalam kehidupan masyarakat. Kedua, Gunungan menjadi lebih tertata, teratur, dan dinamis dalam bentuk penyajiannya. Ketiga, kesenian Gunungan telah mencapai level pantas ditampilkan sebagai sajian wisata di Ketep, Sawangan, Magelang, Jawa Tengah.

\section{SIMPULAN}

Masyarakat di Desa Ketep pada umumnya dan masyarakat di Dusun Gondang Sari pada khususnya, terutama anggota kelompok kesenian Gunungan sangat bersemangat dan berantusias dalam mengikuti program ini. Hal ini diperkuat dengan dukungan penuh dari Lurah Arifin selaku
Kepala Desa Ketep yang juga sangat berantusias. Di dalam setiap latihan, para anggota selalu aktif dan penuh semangat walaupun waktunya sampai larut malam, pun dalam kondisi cuaca khas pegunungan yang sangat dingin.

Pelaksanaan penyuluhan seni ini dilaksanakan dengan metode ceramah, workshop, dan evaluasi. Pada permulaannya, penyuluh memberikan penjelasan secara lisan disertai dengan contoh-contoh gerakan tari secara imitatif. Selanjutnya, dalam workshop, semua peserta melakukan gerak tari baik secara bagian per bagian maupun secara keseluruhan. Yang terakhir, dalam evaluasi penyuluh mengoreksi dan melakukan pembenahan pada gerakan tari, koreografi, dan pola lantai yang belum baik.

\section{SARAN}

Tari Gunungan ini termasuk kesenian baru, yaitu dibuat pada tahun 2016 oleh kelompok kesenian Dusun Gondang Sari dengan bantuan mahasiswa dari ISI Yogyakarta yang pada saat itu sedang mengikuti program P3Wilsen dari LPM ISI Yogyakarta di Kecamatan Sawangan, Kabupaten Magelang. Selanjutnya oleh masyarakat dusun ini, Gunungan dijadikan sebagai salah satu kesenian andalan dan identitas kesenian setempat. Oleh karena itu, masih banyak gerakan tari, koreografi, pola lantai, dan iringan yang perlu mendapatkan pembinaan lebih lanjut agar menjadi lebih baik lagi; seperti pada kesempatan program kegiatan penyuluhan yang diadakan oleh LPM ISI Yogyakarta ini. Dengan demikian, kesenian Gunungan akan tampil lebih menarik dan akan selalu aktif sehingga membuat generasi berikutnya terus mencintai kesenian yang hidup dan berkembang di desanya sendiri. Mereka pun diharapkan akan selalu melestarikan dan mengembangkan kesenian ini. Untuk ke depannya, sesuai dengan arahan Lurah Arifin, 
kesenian Gunungan ini diharapkan dapat disajikan atau ditampilkan sebagai salah satu seni wisata di Ketep, Sawangan, Magelang, Jawa Tengah.

\section{UCAPAN TERIMA KASIH}

Terima kasih diucapkan kepada Ketua LPM ISI Yogyakarta, Dr. Nursahid., M.Hum. dan Kepala Desa Ketep, Lurah Arifin yang telah memberikan kesempatan untuk pelaksanaan program penyuluhan seni ini. Terima kasih diucapkan pula kepada masyarakat Desa Gondang khususnya kelompok kesenian Gunungan atas kerja sama serta antusiasmenya sehingga program penyuluhan ini bisa berjalan dengan lancar.

\section{DAFTAR PUSTAKA}

F.D. Prastiwi. \& N. Farida. (2016). "Pengaruh Daya Tarik dan Word-of-Mouth terhadap

Kunjungan Ulang Melalui Kepuasan. Jurnal Ilmu Administrasi Bisnis, Volume 6, Nomor 1, pp. 68-76, Desember.

Hakim, Arif Lukmanul, (2014). "Sekaten, Sebuah Proses Akulturasi Budaya dan Pribumisasi Islam”, Harian Solopos 17 Maret.

Handipaningrat, KRT. Haji, (1970). "Perayaan Sekaten”. Majalah Relung Pustaka, Juli.

Koentjaraningrat. (1990). Manusia dan Kebudayaan Indonesia. Jakarta: Jambatan.

Sunyoto, Choirudin. \& Angge, Indah Chrysanti. (2016). "Bentuk Gunungan Wayang Kulit Purwa sebagai Ide Pembuatan Liontin dan Kalung. Jurnal Pendidikan Seni Rupa, Volume 04, Nomor 02, pp. 317- 322. 
